Historic, Archive Document

Do not assume content reflects current scientific knowledge, policies, or practices. 

62.47

TULIPS - PEONIES - NARCISSI - IRISES

\title{
Autumn 1929
}

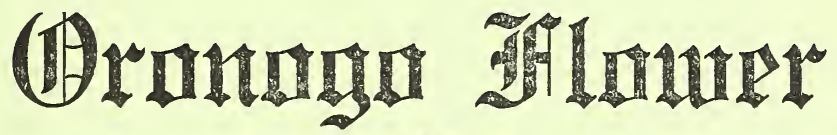

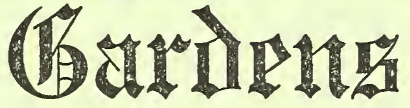

\section{ARTER VILLE, MO.}

\author{
BENJAMIN C. AUTEN
}

Terms: Cash with order. No charge for packing. Goods offered subject to previous sale. All prices include delivery by mail or express.

Items quoted only in small quantities can be furnished only in small quantities, and at the printed prices.

Bulbs shipped on receipt of order, plants in regular routine of digging and shipping. Bulbs and plants not shipped together, nor at the same time.

No guarantee goes with my bulbs or plants, but I take extreme pains to have them true to name, and it is on them I depend for future orders. Write me, however, if you fail to have success with them. It is important for me to know.

If a mistake is made in the filling of your order or the package reaches you in bad condition, write me. I do not know of it unless you do.

If you do not hear from your orders in a reasonable length of time, write. Orders may get lost on the way, may possibly be overlooked after receipt, or the shipment may go astray.

Order early and plant early, while the bulbs are still fresh and solid.

Next year's price list will as a matter of course be sent to all this year's customers, but I do not keep a permanent mailing list.

My own growing only. 


\section{THE FORCING OF BULBS}

The "F" and "FF" varieties of narcissi, the hyacinths, the grape hyacinths, and the Star of Bethlehem are easily brought to bloom in the house in winter.

For success with any of these bulbs, a certain routine is absolutely necessary. After potting or other method of planting, the bulbs must be put where dark and very cool, the colder the better, so they do not freeze, and kept faithfully watered, for as much as two months, unless they make determined growth sooner. When the buds are above ground, or the two months are up, the bulbs can be brought to warmth and light to complete their growth. Do not get them too warm, or the buds will blast, and do not let them stand in strong sun.

The best material I have found for growing bulbs in water is poultry-grit charcoal, hen size. It does not get foul, holds water a long time, and does not obstruct the roots if properly handled. The dish preferably should be of glass, and more than three inches deep.

Fill the dish with charcoal to about an inch from the top, and pour in water until the charcoal floats off the bottom of the dish. Press the charcoal down until it is all under water. Nest the bulbs about half their depth in the charcoal, and add water to float the charcoal for about a week. After that, merely see that there is water standing in the charcoal anywhere from the bottom to the top, all the time. Every ten days or two weeks will be as often as watering will be necessary. Do not remove the bulbs from the charcoal to see if they are rooted. They can not be replaced in the charcoal without injury to the delicate roots and damage to the bulb.

Bulbs of hyacinths, narcissi, etc., grown indoors for winter blooming, should be kept growing until the leaves die down, then set in the ground outdoors, where they can remain at least a year undisturbed.

\section{OUTDOOR GROWING}

Tulip and Narcissus bulbs should be planted about three inches deep to the tops of the bulbs as soon as possible after summer heat and drouth are broken, must remain in the ground over winter, and should not be disturbed until the leaves have turned yellow in early summer. This is the correct time to dig them. Narcissi prefer to be left in the ground several years. Tulips are better dug every year, though they may be let go an extra year if small when planted. Plant about six inches apart.

Bulbs should not be allowed to lie in the sun when dug, nor when planting, nor at any other time. They should be stored cool, dark, and well ventilated.

\section{NARCISSUS BULBS}

My descriptions may seem slight, but, as the list is large, I must save space, and there is nearly a paragraph of description in the key following the name. Every variety is just as fine as if a whole page were written about it, every variety is different from every other, and there is not a poor variety in the list. The prices are moderate, and include prepaid delivery of the bulbs to you.

The Ajax type is the one with the long trumpet; the Incom- 
parabilis has the half length trumpet or cup, the Barrii the quarterlength cup. The Poeticus type has a white flower with a little flat red-edged saucer in the center. The Poetaz, Tazetta, and Jonquil types are bunch flowered and the blooms have small cups. The Leedsii type has medium or small cups and is primrose-white in color. $\mathrm{Y}, \mathrm{W}$, and Bic stand respectively for yellow, white and bi-color (white wing and yellow trumpet or cup). 1, 2, 6 tells the season of bloom. $F$ means that a variety is good for forcing, FF that it is very good.

My supply of some of these bulbs is very small: therefore, where only one or five bulbs of a kind are offered, order only one or five bulbs of those kinds.

Shipped August until winter. Not furnished in the spring.

Prices include delivery by mail or express.

Mixture. A combination of many varieties and types that will give a constantly changing program throughout the season. 10 for 50 c, 25 for $\$ 1.00,100$ for $\$ 3.30,250$ for $\$ 7.50,1000$ for $\$ 30.00$.

Adonia. BarBic5. Stately and refined. A cream-white flower with brilliant cup. 25c.

Alba Plena Odorata. PtW6. The common double white poeticus, the latest of all narcissi. The "gardenia-flowered" narcissus. 7c, 5 for $28 \mathrm{c}, 25$ for $\$ 1.30,100$ for $\$ 4.80,250$ for $\$ 11.00,1000$ for $\$ 40.00$.

Albatross. BarW4FF. Large flower with cup pale citron, faintly edged red. $10 \mathrm{c}, 5$ for $40 \mathrm{c}, 25$ for $\$ 1.90,100$ for $\$ 7.20,250$ for $\$ 16.00$.

Ariadne. LdW3F. Cup ivory white, very broad and spreading. $8 \mathrm{c}, 5$ for $32 \mathrm{c}, 25$ for $\$ 1.50,100$ for $\$ 5.60$.

Bianca. LdW4. A beautiful flower, almost perfectly flat, all white, except the eye, which is bright green. $10 \mathrm{c}, 5$ for $40 \mathrm{c}$.

Blazing Star. IncY3. A truly yellow flower, of dashing style, star shape, with brilliant red-edged cup. A flower of the highest quality in every way. $\$ 2.00$.

Buttercup. JqY4FF. Deep golden yellow, one of the largest of the jonquil hybrids. The jonquil and its hybrids are the richest in color of all the narcissi, of the highest quality, and exquisitely fragrant. $25 \mathrm{c}$.

Campernelle Rugulosus. JqY2FF. Deep golden yellow, richly fragrant. 10c.

Campernelle Rugulosus Maximus. JqY2. Of the same form as the preceding, but a much heavier flower, larger, and richer and more brilliant in color. $25 \mathrm{c}$.

Campernelle Rugulosus Plenus. JqY2. Full double, rich yellow. To my notion one of the best of double narcissi. $12 \mathrm{c}$.

Cardinal. IncY3. Fine. Cup bright red. This variety is not too tall in growth to be acceptable for rock-garden planting. $10 \mathrm{c}$, 5 for $40 \mathrm{c}, 25$ for $\$ 1.90,100$ for $\$ 7.20$.

Cassandra. PtW5F. The ideal poeticus narcissus, and a noble flower, large, of the purest white, with the eye small and well marked. $14 \mathrm{c}, 5$ for $56 \mathrm{c}, 25$ for $\$ 2.70$.

Cervantes. AjY1FF. Pale yellow. An extra fine variety for forcing. $10 \mathrm{c}$.

Chaucer. PtW3F. This is the earliest of the poeticus varieties, and has the reddest eye. $8 c, 5$ for $32 c, 25$ for $\$ 1.50$.

Chieftain. IncY1F. Pale yellow, with large flaring cup. 16c. 
Circlet. BarBic3. Though imported under this name, it undoubtedly is Southern Star. Pointed overlapping petals, cup broad and widely expanded, with edge of bright red. 12c, 5 for $48 \mathrm{c}$.

Conspicuus. BarY4F. One of the old dependables. The deep yellow cup is rimmed rich red. 6c, 5 for $24 \mathrm{c}, 25$ for $\$ 1.10,100$ for $\$ 4.00$. 40c.

Dante. PtW3. One of the choicer poeticus varieties. 10c, 5 for

Elaine. LdW5. An exquisite little silvery-white flower. 10c, 5 for $40 \mathrm{c}$.

Emperor. AjY3FF. The popular large yellow trumpet narcissus, often mistakenly called "jonquil." 10c.

Epic. PtW5. A poets' narcissus much finer than Ornatus, a variety I discarded years ago. $12 \mathrm{c}, 5$ for $48 \mathrm{c}, 25$ for $\$ 2.30,100$ for $\$ 8.80$.

Fairy Queen. LdW2F. The whole flower is snowy white, the cup large and well expanded. 10c, 5 for $40 \mathrm{c}, 25$ for $\$ 1.90,100$ for $\$ 7.20$.

Firebrand. BarBic3. A fiery little flower. 10c.

Fusilier. BarBic3. Creamy white, with wide orange crown. 10c, 5 for 40 c, 25 for $\$ 1.20$.

Gloria Mundi. IncY3. Similar to Sir Watkin, but later, and deeper and richer in color. 12c.

Glory of Sassenheim. AjBic2F. One of the big ones. White perianth, yellow trumpet. Will displace Victoria. 14c, 5 for $56 \mathrm{c}, 25$ for $\$ 2.70,100$ for $\$ 10.40$.

Gold Finch. AjY2. Deep yellow, almost orange. Trumpet short, very wide and flaring. 25c, 5 for $\$ 1.00$.

Grand Duchess. LdW3. Some of the most exquisite of all the narcissi are in the Leedsii group, and this is one of them. Small, delicate, white flower, flushed apricot. 12c.

Grandiflorus. PtW5FF. The largest of the poeticus type, bold and striking in size and form. A husky grower, and highly effective in outside planting, as well as for decorating indoors. 6c, 5 for $24 \mathrm{c}$, 25 for $\$ 1.10,100$ for $\$ 4.00,250$ for $\$ 9.00,1000$ for $\$ 36.00$.

Homespun. IncY3F. Deep sulphur yellow. Unique in color, elegant in form, and destined to become very popular. $12 \mathrm{c}, 5$ for $48 \mathrm{c}$, 25 for $\$ 2.30,100$ for $\$ 8.80$.

Horace. PtW4F. Large flower, tall stem, eye red nearly to the center. This is one of the finest poeticus varieties on the market. 10 c, 5 for 40 c, 25 for $\$ 1.90,100$ for $\$ 7.20$.

Jonquil. JqY5FF. The smallest of the narcissi, surpassing in color, quality, and odor. The leaves are very slender, quill shape. The bulbs are very small, and should be planted only two inches deep. 6c.

King Alfred. AjY2FF. The first favorite of all narcissi in commerce at the present time. One of the big ones. 20c.

Lecnie. IncY3FF. Pale yellow, cup large and flaring. A choice flower on a fine stem. 12c, 5 for $48 \mathrm{c}$.

Lord Kitchener. LdW3. One of the giant Leedsii, and a very popular flower. $25 \mathrm{c}$.

Lucia. LdW4F. A tall, stately flower, very chaste in form and coloring. Especially beautiful when forced. $10 \mathrm{c}$, 5 for $40 \mathrm{c}$.

Lucifer. IncBic3F. A large white flower, which carries itself 
in superb style. The long, slender cup is shaded to bright red at the edge. $11 \mathrm{c}, 5$ for $44 \mathrm{c}, 25$ for $\$ 2.10$.

Lycidas. PtW3. An especially beautiful poets' narcissus. 20c.

Monarch. AjY3FF. Similar to Emperor, but better in quality and color. 25c, 5 for $\$ 1.00$.

Northern Queen. BarW5. This kind is of interest to those who wish to get as many varieties as possible in their plantings. 10c, 5 for $40 \mathrm{c}$.

Pheasant Eye. PtW6. The common late white narcissus. 6c.

Queen of the North. LdW3. Similar to White Lady, but a finer variety. $12 \mathrm{c}, 5$ for $48 \mathrm{c}$.

Red Chief. BarW5. This pretty white flower has a large flattened cup with edge rich orange and heavily crimped. 20c.

Red Star. IncBic5. White flower, very late, with long slender cup heavily stained rich red. $12 \mathrm{c}$.

Sirdar. LdW3F. Another of the Giant Leedsii, about the size of Sir Watkin, but a much more massive flower, more robust, and bolder in effect. It is white, of course, as are all the Leedsii. 25c, 5 for $\$ 1.25$.

Sir Watkin. IncY2FF. "The Giant Welshman." The largest early incomparabilis, and one of the leading favorites of all narcissi. 10 c, 5 for 40 c, 25 for $\$ 1.90,100$ for $\$ 7.20,250$ for $\$ 16.60,1000$ for $\$ 64.00$.

Stella Superba. IncBic3. A large yellow flower with cup of deeper yellow. 10c.

Torch. IncY3. Large, rich yellow, with brilliant red cup. 16c.

Tresserve. AjY4. One of the finer new lkinds of large trumpet narcissi. $25 \mathrm{c}, 5$ for $\$ 1.00$.

White Lady. LdW4F. A large, flat flower on tall stem. Cup small, heavily crinkled, citron yellow. Very stately. 8c, 5 for 32c, 25 for $\$ 1.50,100$ for $\$ 5.60$.

Whitewell. IncBic4. A large creamy-white flower of refined form and heavy substance, with a large flaring cup of deeper color. $16 \mathrm{c}$.

If price is given for only one bulb of a variety, order only one bulb of that variety: if only five of a variety are priced, order no more than five of that variety.

As I can not dig all varieties every year, many of those in this list will not appear again for two or three years.

For blooming indoors during the winter, select only "FF" and "F" varieties. For early bloomers, select " 1 " and " 2 " varieties, for early midseason flowers " 3 " varieties, for late midseason " 4 " varieties, and for late flowers " 5 " and " 6 " varieties.

Most so-called "yellow" narcissi can be so described only as a matter of courtesy. If you want a flower really yellow, get the jonquil or one of the jonquil hybrids, or Gold Finch, Gloria Mundi, Torch, or Blazing Star.

Do not be afraid to buy narcissus bulbs. The money paid for them is not spent, but invested, invested in property that not only will give annual dividends, increasing every year, in flowers, but will of itself increase at a rate much greater than any legal rate of interest. 


\section{MISCELLANEOUS BULBS}

Not furnished in spring, except the tuberose and the common garlic. Prices include delivery.

Grape Hyacinth. Deep purple-blue. Should be planted only two inches deep, preferably where cool, moist, and a little shady. 5c, 6 for $20 \mathrm{c}, 12$ for $36 \mathrm{c}$.

Hyacinths. One of the finest bulbs for winter blooming indoors. In outdoors planting they should be set about four inches deep to the tops of the bulbs. I have them only in mixture, and in mixed sizes. medium and small. A good twenty-five cents' worth, 25c.

Giant Garlic. While this is good for cooking, like the common garden garlic, it is especially as a flower that I am offering it here, for outdoor planting in the fall. It gives a large ball, like the bloom of a seed onion, but at the top of a stem four feet tall, and a vivid pinkish blue in color. The bulbs grow to weigh one-half pound or over. $15 \mathrm{c}, 2$ for $25 \mathrm{c}$.

Garlic. This is an improved form of the common garden garlic. It is fine for use in cooking, especially for the flavoring of meats. Restaurant chili always has garlic in it. One-fourth lb., 15c; one lb., $50 \mathrm{c}$.

Winter Onions. Stand in the ground the year around. Thinnings from the row give green onions any time of year from early winter until summer. One-half pound, 15c. Should be planted in early fall.

Tuberose. This is a double variety I have never seen catalogued. I take it to be the old original double tuberose that was superseded by the common Double Dwarf Pearl. The stem is very tall, the double flowers exquisite in form, color and odor, much like the Pearl. The flowers are spaced farther apart on the stalk than those of Pearl.

Pearl may be all right in much of the country, but here it fails utterly to open its buds, except such stalks as chance to come in the cool fall season. This variety opens its flowers to perfection despite heat and drouth, and is a much more graceful spike, not so heavy and club-like. 15c, 2 for 25c, fall or spring delivery, as desired. The tuberose is not hardy, must have spring planting, and the bulb must be stored over winter free of frost. Planting should be delayed until the ground is warm, though the bulbs may be started earlier in pots. Any bulbs that are showing buds on the approach of frost can be taken indoors to bring the buds to flower.

\section{TULIP BULBS}

Shipped August until winter. Not furnished in spring.

Do not attempt to grow any of these tulips indoors. They are for outdoor growing only.

Prices include delivery by mail or express.

Mixeduluaterimaln utter riot of color nothing can surpass a bed of mixed late tulips. The prevailing colors are white, yellow, pink, orange, red, and variegated. This mixture is madewu wholly of named varieties, and contains a great many of them. 12 for 360,25 for $60 \mathrm{c}$, 100 for $\$ 2.00,250$ for $\$ 4.50$.

Avis Kennicott. One of the finest of yellow tulips. 10c.

Bouton d'Or. Rich golden yellow, with black anthers. The nearest like a Darwin of any yellow tulip. 5c, 3 for $12 \mathrm{c}, 12$ for $40 \mathrm{c}$.

Columbus. A stunning flower, sharply pointed, yellow, striped scarlet, and very beautiful. $10 \mathrm{c}, 3$ for $25 \mathrm{c}, 12$ for $80 \mathrm{c}, 25$ for $\$ 1.50$. 
Flava. A superb tulip, pale yellow, very late. 16c.

Inglescombe Yellow. Unjustifiably called "The Yellow Darwin." It is not like the Darwins, and is too late to blossom in their company, but is a beautiful flower, cup shaped, of purest sulphur yellow. $5 c, 3$ for $12 c, 12$ for $40 c, 25$ for $70 c$.

Mrs. Moon. Pure clear yellow. Tall stem, pointed flower. A fine cut-flower variety. $7 \mathrm{c}, 3$ for $18 \mathrm{c}, 12$ for $60 \mathrm{c}$.

\section{Darwin Type}

Mixed Dowwins While this mixture contains most of the Darwin colors, it is composedwmostly of varieties not represented in the list below. 12 for $40 \mathrm{c}, 25$ for $70 \mathrm{c}, 100$ for $\$ 2.40,250$ for $\$ 5.40$.

Afterglow. Apricot-orange, edged salmon. 10c, 3 for $24 \mathrm{c}$. 30c.

Bleu Celeste. One of the finest of dark blue tulips. 12c, 3 for

Clara Butt. Apricot pink, an exquisite color. The first favorite of all tulips. $5 c, 3$ for $12 c, 12$ for $40 \mathrm{c}, 25$ for $70 \mathrm{c}, 100$ for $\$ 2.40$, 250 for $\$ 5.40$.

Electra. "Soft rosy lilac. A pale variety of great beauty." 7c, 3 for $18 \mathrm{c}, 12$ for $60 \mathrm{c}$.

Elephant. It is probably from its color that this variety gets its name. 50c.

Farncombe Sanders. The loveliest of red tulips, and second in favor only to Clara Butt. 7c, 3 for $18 \mathrm{c}, 12$ for $60 \mathrm{c}$.

Faust. One of the finest of the nearly black tulips. 8c.

Jubilee. Deep purple. Very late. 10c.

King George V. Brilliant red, and a very large flower with fine stem. 16c.

La Tristesse. Dull slaty blue. One of the finest of blue tulips. $6 c, 3$ for $15 c, 12$ for $48 c$.

L'Ingenue. Soft rose. 8c.

Massenet. Apple-blossom pink. A superb tulip. 10c, 3 for 25c.

Moralis. Very fine dark blue. $7 \mathrm{c}, 3$ for $18 \mathrm{c}$.

Opal. Heliotrope-lilac. 7c, 3 for $18 \mathrm{c}$.

Painted Lady. Heliotrope-white. One of the unexplainable colors found in so many of the Darwin tulips. 6c, 3 for $15 \mathrm{c}, 12$ for $48 \mathrm{c}$.

Princess Elizabeth. Bright rosy pink. $7 \mathrm{c}, 3$ for $18 \mathrm{c}$.

Rev. Ewbank. Beautiful heliotrope. One of the most brilliant of the blues. $6 \mathrm{c}, 3$ for $15 \mathrm{c}$. for $40 \mathrm{c}$.

The Bishop. Pure violet. A massive flower and plant. 15c, 3

Velvet King. Deep velvety brown. 10c.

Yellow Perfection. This is a breeder, olive yellow, another unexplainable color. 8c.

As my supply this year of named varieties is very small, except of Clara Butt, please do not order more of a variety than the quantity offered.

\section{BEARDED IRISES}

The bearded irises should be planted shallow, and should be given as nearly as possible, a dry, well-drained location in full sun. A dressing of some form of lime or limestone is very beneficial. 
Furnished any time of year except winter.

Prices include delivery by mail or express.

Mixture. 25 plants in at least 5 varieties, my selection, $\$ 1.50$, 100 plants, in at least 15 varieties, my selection, $\$ 5.00$.

Alcazar (?). Massive plant, flower violet and purple. 20c.

Ambassadeur. Lavender and deep red-violet. 50c.

Archeveque. Two shades of dark purple. 20c.

Aurora. Beautiful light blue. 25c.

Black Knight, Black Prince. In color effect one of the richest of all irises. 30c.

Cengialti. Similar to Pallida Dalmatica, but smaller, deeper in color, daintily crinkled, and richly fragrant. For color mass it is superior, being more profuse in bloom, and richer and more brilliant in color. $15 \mathrm{c}, 6$ for $60 \mathrm{c}$.

Citrea (?) Pumila. Extra early, low growing, dark greenish lemon-yellow. 15c, 6 for $60 \mathrm{c}, 25$ for $\$ 2.00,100$ for $\$ 6.00$.

Claret Pink. Name unknown. 15c, 6 for 60 c, 25 for $\$ 2.00,100$ for $\$ 6.00$.

Crusader. Dark blue. 35c.

Early Dark Blue. Name unknown. The finest early dark blue I know. 15c, 6 for $60 \mathrm{c}, 25$ for $\$ 2.00$.

Early White. This I suppose is Albicans, Princess of Wales. It is the finest early white iris I know, purer in color, and earlier and more profuse in bloom than Florentina. 15c, 6 for $75 \mathrm{c}, 25$ for $\$ 2.00$, 100 for $\$ 6.00$.

Ed. Michel. Deep reddish violet. 25c.

Fairy (?). A large flower of Pallida form, white with blue shadings, very fragrant. One of the loveliest of all irises. 15c, 6 for 75 c, 25 for $\$ 2.50$, 100 for $\$ 8.00$.

Florentina. Early, pearly gray-white. The rhizomes, peeled and dried, are the orris root used in perfumery. 15c, 6 for $60 \mathrm{c}, 25$ for $\$ 2.00,100$ for $\$ 6.00$.

Honorabilis. The old yellow and brown. 15c, 6 for 60 c, 25 for $\$ 2$.

Innocenza. Late. Rich brilliant ivory-white. 15c, 6 for $75 \mathrm{c}$, 25 for $\$ 2.25,100$ for $\$ 7.20$.

Juniata. Like Pallida Dalmatica, but darker and larger. 15c, 6 for $75 \mathrm{c}$.

Kochii. Early. Buds soot-black, flower deepest purple. 15c, 6 for 75 c.

Koenig. King of Iris. Smoky yellow and rich brown. Very large One of the finest irises. 15c, 6 for $75 \mathrm{c}$.

La Neige. Unsurpassed in snowy whiteness. 20c.

Light and Dark Blue. Name unknown. Large flower with broad petals. Early. 15c, 6 for 60c, 25 for $\$ 2.00,100$ for $\$ 6.00$.

Mme. de Sevigne. A variety of the frilled type, with very dark edging. 15c.

Mother of Pearl. Pale rosy blue. 50c.

Pallida Dalmatica. Plant large, tall, and stately. Flower very large, soft lavender in color. $15 \mathrm{c}, 6$ for $75 \mathrm{c}, 25$ for $\$ 2.50,100$ for $\$ 8$.

Perfection. Light blue and very dark purple. 15c, 6 for $75 \mathrm{c}$.

Pfauenauge. Dull yellow and plum-purple. A stately flower. 15c. 
Princess Victoria Louise (?). Standards light yellow, falls purple, edged yellow. 15c, 6 for 60 c, 25 for $\$ 2.00,100$ for $\$ 6.00$.

Prosper Laugier. Blended shades of bronze, red, and purple. One of the richest in color of all the irises. $15 \mathrm{c}, 6$ for $75 \mathrm{c}$.

Quaker Lady... An exquisitely dainty flower, of smoky grayblue effect, enriched with faint suffusions of old gold. 15c, 6 for $75 \mathrm{c}$.

Queen Caterina. Pale bluish lavender. 35c.

Queen of May (?). Lavender-rose. A beautiful flower and a strong plant. $15 \mathrm{c}, 6$ for $60 \mathrm{c}, 25$ for $\$ 2.00,100$ for $\$ 6.00$.

Rhein Nixe. Standards white; falls blue, with white border. Very large. 15c, 3 for $40 \mathrm{c}, 6$ for $75 c$, 25 for $\$ 2.25$.

Romeo. Yellow and rich purple. 25c.

R. R. Smith. Similar to Queen Caterina, of equal quality, a little more refined in color, being shaded at the haft, instead of reticulated. A little smaller, but still a large flower. 25c.

Sherwin-Wright. The favorite pure yellow. 15c, 6 for $75 \mathrm{c}, 25$ for $\$ 2.00,100$ for $\$ 6.00$.

Souv. de Mme. Gaudichau. Rich dark purple. 60c.

The bearded irises do well planted along foundations on the south and west sides, where it is too hot and dry for anything else.

All dead iris leaves should be gathered and burned before winter.

\section{BEARDLESS IRISES}

These thrive in any good garden location, but especially enjoy a location by the waterside. Pseudacorus will also grow standing in water. Furnished in spring or fall.

Prices include delivery.

Snow Queen. White, with yellow blotch. 20c, 6 for $\$ 1.00,12$ for $\$ 1.80,25$ for $\$ 3.00,100$ for $\$ 9.00$.

Perry's Blue. Light blue, large flower. Stem very tall, holding the flowers well above the foliage. $40 \mathrm{c}, 3$ for $\$ 1.00$.

Distinction. Rich blue, with white veining. Stem very tall. A flower of remarkable grace and beauty, an outstanding gem of the flower world. $20 \mathrm{c}, 6$ for $\$ 1.00,12$ for $\$ 1.80,25$ for $\$ 3.00,100$ for $\$ 9.00$.

Emperor. Deep purple-blue, mammoth flower. Stem very tall. 40 c, 3 for $\$ 1.00$.

Four Siberians. One plant each of the four varieties. $\$ 1.00$.

Besides these I have also Pale Blue, Butterfly, Blue King and Dark Blue (Sanguinea?), which I can furnish at the same price as Snow Queen. I do not recommend them except in case low-growing plants are desired. Pale Blue and Butterfly are the same color as Perry's Blue. Dark Blue is perhaps slightly deeper in color than Emperor.

Pseudacorus. Foliage tall, and the handsomest of all irises. Flower flat, a deep golden yellow with black markings. 20c, 3 for 50 c, 12 for $\$ 1.50$.

Versicolor. The common wild water-flag. Pale lavender. 20c.

Ochroleuca. Orientalis Gigantea. A superb flower, pure ivorywhite, with yellow blotch on the falls. $25 \mathrm{c}, 6$ for $\$ 1.20,12$ for $\$ 2.25$, 25 for $\$ 4.00$. 
Longipetala Superba. Spuria Mrs. A. W. Tait. This in type is like Ochroleuca, but a dainty lavender in color. 25c.

Monspur. Like Ochroleuca, but deep blue, with yellow blotch. 75c.

Dorothea K. Williamson. Dark purple-blue, and a profuse bloomer. 40c.

Fulva. Copper colored. A unique color and flower, and valuable for breeding. 40c. 3 for $\$ 1.00$.

Hexagona Lemancei (?). Foliosa (?). Blue. 25c.

\section{MISCELLANEOUS PLANTS}

Furnished in the fall. Prices include delivery.

Lily of the Valley. One of the most loved of all flowers. Rooted runners, each carrying a growth-bud, or "pip." Blooming size, 10c, 3 for $25 \mathrm{c}, 8$ for $50 \mathrm{c}$. Smaller size, 5c, 4 for $15 \mathrm{c}, 12$ for $40 \mathrm{c}, 25$ for $75 \mathrm{c}$.

Hemerocallis, Flava. The familiar lemon lily. 20c.

Hemerocallis, Queen of May. Probably the grandest of all the yellow day-lilies. Later than Flava. Flowers of extreme size, rich yellow. This variety creates a sensation wherever introduced. Exquisitely fragrant, and continues in bloom several weeks during midsummer. 25c, 6 for $\$ 1.25$.

Coral Bells. Hardy outdoors, and also a perfect house-plant, in bloom about two months. This variety is pink, slightly lighter in color than the regular Coral Bells. Crown divisions, 20c.

Hardy Sweet Violet. 15c.

Hardy White Violet. Large snowy flowers borne in greatest profusion above the foliage. $15 \mathrm{c}$.

Hardy Blue and White Violet. Like the preceding, but with blue center. $15 \mathrm{c}$.

Hardy Violet, Snowflake. Dark blue, with snow-white spots. 15c.

Blackberry Lily. An old-time flower. The plant looks like an iris, the flower much like a montbretia, and the burst seed-pod like a big ripe blackberry. The flowers are bright and showy, orangered, spotted darker, at a height of about two feet. Hardy. 25c.

Artemisia, Silver King. A beautiful foliage plant, leaves and stems a uniform silvery gray-white. When cut in bud stage it dries without wilting or any other change in appearance, and makes a beautiful winter bouquet. Perennial, perfectly hardy, but I suggest it be used as a houseplant through the winter, and set out in spring. $25 \mathrm{c}$.

Bryophyllum. A curiosity plant. Lay a leaf on the moist soil of a flower pot, and soon young plants will grow from the notches in the edge of the leaf. Grows with great rapidity. A house-plant only, as it can not stand a touch of frost. A leaf, 10c, if with other goods: otherwise, 15c.

Wax Plant. Hoya Carnosa. This is an old-time favorite and as a plant is one of the finest that can be grown. The leaves are thick and leathery, glossy deep green. The flowers can not be surpassed in beauty, either in color or in perfection of form. They are delicate pink, star shaped, in clusters. The plant is a vine, a houseplant only, as it can not stand frost. Small plants, $75 \mathrm{c}$. Larger plants, $\$ 1.50$ and $\$ 2.50$. 


\section{PEONIES}

Plants should be set as soon as received, placing so that the buds will be about two inches below the leveled surface of the soil when planting is completed. In the open field or garden, like corn and potatoes, and with the same kind of care, peonies do famously. Where the soil is killed by elms, maples or poplars, or is starved and dried out from other reasons, nothing can be expected of them. They also will not thrive in soggy ground.

Prices quoted are for strong divisions from mature plants.

If peonies are desired in quantities of 25 or more of a variety, totaling 100 or more plants, special prices can be given for many of the varieties.

Prices include delivery by mail or express. If the customer prefers to pay the transportation costs, $6 \mathrm{c}$ per plant may be deducted from the face of the order.

The rate for 3 applies only to 3 of 1 kind. It does not apply to 1 each of 3 kinds. Likewise any other quantity rate.

Where only the one price is given, additional plants of that variety are at the same price; for example, three of Humei would be $\$ 1.20$, five of Mikado would be $\$ 5.00$, etc. Similarly the price of twelve Constant Devred would be $70 \mathrm{c}$ each, or $\$ 8.40$, etc.

Shipments begin about September 1. Fall delivery only.

\section{Single Varieties}

Mixed Singles. Various colors, not including the varieties listed below. $40 \mathrm{c}, 3$ or more at $30 \mathrm{c}$ each, 10 or more at $25 \mathrm{c}$ each.

8.4. Albiflora, The Bride. Flowers very large, blush white when opening, pure white when open. $80 \mathrm{c}, 3$ or more at $75 \mathrm{c}$.

7.1 Darkness. Brand. Darkest red, and of exceptionally high quality. $\$ 1.60$.

8.6 Mikado. One of the finest of bright red peonies. At this price no one can afford not to have one. \$1.00. Japanese type.

Single Tall Red. A good plain red, tall, a healthy and husky grower. $40 \mathrm{c}, 3$ or more at $30 \mathrm{c}$ each, 10 or more at $25 \mathrm{c}$ each.

For planting effect, for indoor decoration, for color masses indoors or out, for profusion of bloom, for lightness, airiness and dainty grace, the singles are not surpassed.

\section{Double Varieties}

Mixture. 3 plants, red, white, pink, my selection, $\$ 1.00$.

7 plants, all different, all labeled, my selection, $\$ 2.00$.

My selection, one plant of each variety labeled; 25 plants in 7 varieties, $\$ 7.50$; 50 in 11 varieties, $\$ 14.00 ; 100$ in 15 varieties, $\$ 26.00$. (If not prepaid, $\$ 6.00, \$ 11.00$, and $\$ 20.00$ respectively).

8.7 Albatre. White, faintly tinted blush. 60c.

8.1 Asa Gray. Light pink, thickly sprinkled with dots of deeper color. $60 \mathrm{c}$.

7.8 Augustin d'Hour. Dark solferino-red. A brilliant and very beautiful flower. $60 \mathrm{c}, 3$ or more at $54 \mathrm{c}, 10$ or more at $50 \mathrm{c}$.

9.0 Baroness Schroeder. Fluffy white, flushed light baby-pink. One of the most beautiful of all peonies, both in flower and in foliage. $80 \mathrm{c}, 3$ or more at $72 \mathrm{c}, 10$ or more at $67 \mathrm{c}$. 
6.7 Bernard Palissy. Large heavy blooms of blush-pink. Late. $60 \mathrm{c}, 3$ or more at $50 \mathrm{c}$.

8.4 Chestine Gowdy. A fine flower, creamy white, tinted pink, of great substance, and a fine keeper when cut. $\$ 1.00$.

8.7 Claire Dubois. The same color as Mons. Jules Elie. One of the finest and most dependable of the late-pink peonies. $60 \mathrm{c}, 3$ or more at $54 \mathrm{c}, 10$ or more at $50 \mathrm{c}$.

7.5 Constant Devred. Vivid rose-carmine. Massive flower. Very late. $80 \mathrm{c}, 3$ or more at $70 \mathrm{c}$.

8.1 Couronne d'Or. Large white flower lighted up with yellow stamens. A sturdy grower and a sure bloomer. $40 \mathrm{c}, 3$ or more at $30 \mathrm{c}$.

6.6 Crimson Victory. A bright clean red in color, and a good flower. $60 \mathrm{c}, 3$ or more at $50 \mathrm{c}$.

7.1 Delachei. Rich brilliant dark red. 40 c, 3 or more at 30 c.

7.6 Delicatissima. Pearly lilac-rose. A profuse bloomer that can be depended on. $40 \mathrm{c}, 3$ or more at $30 \mathrm{c}$.

8.1 Duchesse de Nemours. One of the loveliest of all white peonies. Opens pale sulphur-white, with greenish center. $40 \mathrm{c}, 3$ or more at $30 \mathrm{c}$.

8.3 Eugene Bigot. A superb red peony superbly mounted on tall straight stem. $80 \mathrm{c}$.

8.3 Wugene Verdier. Baby-pink and cream. Massive flower and stem. $80 \mathrm{c}, 3$ or more at $72 \mathrm{c}$.

8.6 Eugenie Verdier. Hydrangea-pink, with opalescent tints. One of the most beautifui of pink peonies. $60 \mathrm{c}, 3$ or more at $50 \mathrm{c}$.

8.4 Felix Crousse. Probably the most popular of all red peonies. $60 \mathrm{c}, 3$ or more at $50 \mathrm{c}$.

9.3 Festiva Maxima. Probably the most popular of all white peonies. Massive grower, sure bloomer, early. $40 \mathrm{c}, 3$ or more at $30 \mathrm{c}$. at $30 \mathrm{c}$.

5.8 Fragrans. Dark rose, exquisitely fragrant. 40c, 3 or more

Giant Pink. Name unknown. Clear dark pink, enormous flower and plant. To my notion can to advantage replace Mme. Geissler, Alexandriana, and Mme. Ducel. $60 \mathrm{c}, 3$ or more at 50c.

8.2 Gigantea. Dark pink, exquisitely fragrant. $\$ 1.00$.

7.9 Gloire de Ch. Gombault. Pink and amber, rich in color, and a fine keeper as a cut flower. $60 \mathrm{c}, 3$ or more at 54c.

7.3 Golden Harvest. Pink and cream. A fine landscape variety. $40 \mathrm{c}, 3$ or more at $30 \mathrm{c}$. red. $80 \mathrm{c}$.

8.2 Grover Cleveland. A superb flower, full double and deep

8.1 Hercules. Fresh light pink. Very large full flower. 40c, 3 or more at 33c.

5.7 Humei. Enormous late dark pink. Strong grower. 40c.

6.5 Humei Carnea. An old variety, too good to permit to be lost in the scramble for new things. A clean pink in color. $60 \mathrm{c}$.

7.2 Irma. Large flower of rich pink. $60 \mathrm{c}$. 
8.8 Karl Rosenfield. A glorious flower, rich glowing crimsonscarlet. Perhaps the most stunning of all peonies. $60 \mathrm{c}$.

6.0 Lady Leonora. Medium pink. Rich color and fragrance. 40c.

Lavender Rose. Tall strong grower, and a striking landscape variety. A Hollis seedling. $40 \mathrm{c}, 3$ or more at $30 \mathrm{c}$.

9.0 La France. One of the most superb of all peonies. Rich opalescent pink. $\$ 2.40$.

7.2 L'Eclatante. An old red variety which lately has been advancing in price. $50 \mathrm{c}$.

8.1 Livingstone. Massive late dark pink. 50c.

6.9 Louis van Houtte. One of the best reds, and one of the surest to give satisfaction. $40 \mathrm{c}, 3$ or more at $33 \mathrm{c}$.

6.4 Lutea Plenissima. Sulphur-white, center green, small flower. There is no daintier peony than this. $40 \mathrm{c}, 3$ or more at $30 \mathrm{c}$.

6.5 Mme. Breon. Very similar to Mme. de Verneville, but with pink outer petals and cream center. $50 \mathrm{c}, 3$ or more at $40 \mathrm{c}$.

7.3 Mme. Bucquet. Glowing darkest red. 50c, 3 or more at $40 \mathrm{c}$.

7.9 Mme Crousse. Purest snowy white. Pure rose fragrance, rich and powerful. $40 \mathrm{c}, 3$ or more at $30 \mathrm{c}$.

7.9 Mme. de Verneville. Rosy or creamy white, changing to pure white. Early, and one of the best peonies for any and all purposes. $40 \mathrm{c}$. 3 or more at $30 \mathrm{c}$.

8.5 Mme. Emile Galle. Exquisitely dainty white, with opalescent tints. $50 \mathrm{c}, 3$ or more at $40 \mathrm{c}$.

7.7 Mme. Forel. One of the all-around best of the late darkpink peonies. $50 \mathrm{c}, 3$ or more at $40 \mathrm{c}$.

9.4 Mme. Jules Dessert. Delicate flesh-pink. Superb in every way both as flower and as plant. $\$ 2.00$.

8.1 Mlle. Rousseau. Tinted white. Tall strong stem. 80c.

8.2 Narcelle Dessert. A high-topped flower of very distinct beauty, milk white, faintly dotted lilac. The stems and leaf-veins are dark red, making the plant very striking. $80 \mathrm{c}, 3$ or more at $72 \mathrm{c}$.

7.5 Marechal Vaillant. Dark mauve-pink. Large and brilliant flower. Late. $40 \mathrm{c}, 3$ or more at $30 \mathrm{c}$.

8.4 Marguerite Gerard. Large broad flower of pale hydrangeapink. $40 \mathrm{c}, 3$ or more at $30 \mathrm{c}$.

6.5 Meissonier. Brilliant crimson, midseason. 10c, 3 or more at $33 \mathrm{c}$.

9.0 Milton Hill. One of the finest of the modern pink varieties. $\$ 3$. 44c.

7.8 Modele de Perfection. Rich pink. Late. 50c, 3 or more at

7.8 Podeste Gruerin. Solferino-red, a very clean fresh color, 60c, 3 or more at $50 \mathrm{c}$.

8.3 Hions. Dupont. Similar to Couronne d'Or, flower broader and more open, waxy white. $40 \mathrm{c}, 3$ or more at $33 \mathrm{c}$.

9.2 Mons. Jules Elie. Pearly violet-rose. A massive flower. $80 \mathrm{c}$, 3 or more at $72 \mathrm{c}$. 
8.8 Mons Martin Cahuzac. Garnet-red. The darkest peony and the finest of dark peonies. $\$ 1.00$.

6.3 Mons. Paillet. Uniform delicate pink. 40c.

6.0 Myrtle. Beautiful, sweet and charming. Discredited by the authorities, but her only fault is that she is not big and fat. 60c.

8.5 Octavie Demay. Beautiful pale pink. Very early. 50c, 3 or more at $45 \mathrm{c}$.

Officinalis Rubra. The old-fashioned early double red peony. 60c.

7.6 Pierre Dessert. One of the pre-eminent red peonies. Dark red, without sheen or gloss, yet tright by indoor light. Massive in flower and in plant. $60 \mathrm{c}, 3$ or more at $50 \mathrm{c}$.

8.2 Pierre Duchartre. Uniform lilac-pink in color. Tall, with strong stems. An extra-fine variety. $60 \mathrm{c}, 3$ or more at 54c.

6.9 Prolifera Tricolor. Pink outer petals, yellow center. This variety is more than one hundred years old, and the yellowest yet. 50c.

7.8 Queen Emma. Rich light pink and cream. A valuable commercial variety. $60 \mathrm{c}$.

8.8 Richard Carvel. Brand. The finest early red peony. $\$ 2.00$.

Sarcoxie. A vivid, very dark red. Tall, and a very easy opener. $80 \mathrm{c}, 3$ or more at $72 \mathrm{c}$.

9.7 Solange. Coffee-tinted pink. A superb variety in every respect, and unique and beautiful in color. $\$ 2.00$. at $30 \mathrm{c}$.

6.6 Sulphurea. Sulphur-white, richly fragrant. 40c, 3 or more $\$ 2.40$.

9.8 Therese. Violet-rose. A pink peony of unsurpassed beauty. 60 c.

8.3 Venus. A beautiful pink variety, with extremely tall stems.

9.3 Walter Faxon. Pink. Unique in the quality and richness of its color. $\$ 3.00$.

When you read disparaging remarks about peony varieties of low quality, bear in mind that the poorest peony on the market gives a finer flower for the price than almost any other perennial in the catalogue. To one in the business of propagating stock, the highestpriced varieties are worth their cost, just as the highest-priced animals are worth their cost to a live-stock breeder; but for every-day garden use in quantities the difference in the flowers does not justify the extra price except to the millionaire, to whom a few dollars mean nothing, or to the flower lover, to whom one plant of an exquisite variety is worth a sacrifice.

Mme. de Verneville as a producer of white flowers and Delicatissima of pink, are in peonies what the White Leghorn is among hens as a producer of eggs.

A peony that can qualify as a commercial variety is valuable for all other purposes.

Bulbs and peonies can make money for you. They work while you sleep.

Bulbs are like eggs: they do not get better by keeping longer. 
It is much the fashion nowadays to stick up the nose at any peony that is not big, fat, clumsy and stupid, relegating beauty of color, daintiness and grace to secondary consideration.

The Peony Society ratings are useful, and valuable, as suggestions, but can prove false gods if worshiped. Their worst fault is that they reverence too much the fat-hog type of flower. Why isn't a trim shoat as beautiful as a fat hog?

Peonies for Fall, 1930, can be ordered from this list.

For use out of water a flower that is fully open or even a little stale will usually hold fresh longer than a freshly-opened, or budsy one.

For ivy poison and other rashes apply Epsom salts, barely dissolved with a little water.

I have been a hay-fever patient for many years, and have learned from experience that an antacid treatment reduces the severity of the affliction from pitiful agony to mere disagreeable discomfort. I have had good results with common baking soda, but Citrocarbonate (Upjohn) is more pleasant to take, much easier on the stomach, and probably better also in other ways.

For additional relief I use Estivin (Schieffelin). When using these two helps I would hardly know I have hay fever except when I am compelled, as sometimes happens, to work at the field among: the weeds whose pollen is the cause of the affliction.

In so-called "serums" for the prevention or cure of hay fever I have no faith whatever. There is no argument by analogy from the use of serums for small pox, rabies, typhoid, diphtheria, tetanus, etc., for the analogy is not there. Hay fever has no tendency toward selfimmunization, and does not induce resistance to itself by the development of leukocytes, antibodies, or whatnot. The statement is made, sometimes at least, in behalf of the serums that people who grow up from childhood associated with the hay-fever plants do not have hay fever, but is false. I myself am a case, and I know others. I grew up from birth in a ragweed and dogfennel town, and used to vie with the other youngsters snuffing fennel blossoms to see who could sneeze the hardest.

Please do not write letters on your order sheet, nor write orders in your letters. Have the letter and the order on separate sheets. Also it will be a help if you will write your bulb and your plant order on separate sheets.

For your own pleasure and profit subscribe to The Flower Grower, Calcium, N. Y. The rates are for one year $\$ 2.00$, for 3 years $\$ 4.50$, for $\$ 5$ years $\$ 6.00$.

Iris lovers need and will appreciate Mr. Walter Stager's book, The Bearded Iris, published by The Flower Grower. Price, \$2.00. Orders for the magazine and the book can be sent to me, or direct to the publisher. 


\section{FERTILIZERS}

The most highly concentrated possible to produce, all water soluble, no waste, no residue to damage the soil, all available, odorless, colorless. Especially adapted to use for potted plants, garden, lawns. For use in small quantities, dissolve one teaspoonful to the gallon of water.

Floranid. The best nitrogen plant food. Sample size, 10c. 1lb. can, ordered with bulbs, 50c; by mail, alone, $65 \mathrm{c}$.

Nitrophoska. The best combined nitrogen, phosphorus and potash plant food. Sample size, 10c. 1-lb can, ordered with bulbs, 35c; by mail, alone, 50c.

Full directions with the package.

Write for prices if larger quantities are wanted. 